\title{
The Traces of Schools \\ in Graduates' Ideas about a Career
}

\author{
Larisa A. Novopashina* and Evgenia G. Grigoryeva \\ Siberian Federal University \\ 79 Svobodny, Krasnoyarsk, 660041, Russia
}

Received 21.08.2014, received in revised form 15.09.2014, accepted 14.11.2014

This article continues the series of authors' publications on the results of the survey conducted in 2011 The Traces of the Specific Features of Educational Program and School in Graduates' Biography. Determining factors of career settings in life trajectories is a relatively new challenge. The results of the factor analysis can explain the differences in the perception of career motivation among graduates of different schools.

Keywords: career, career attitudes, life trajectories, the education system.

Research area: psychology.

\section{Introduction}

In this article we continue to discuss the results of the survey that was conducted within the research project «Factor of schools in education and employment trajectories of graduates» jointly performed by IPPD (Krasnoyarsk) and HSE (Moscow). The research question about the impact of the schools on the trajectory in their graduates' lives remains crucial and actual. In the previous publications we examined the expression of a factor of schools in educational trajectories $(1,3)$; in the events of life (3); in the characteristics of responsibility (2) and showed that the factor of schools as a whole does not affect life trajectories. At the same time, it was found that these factors of schools appear in satisfaction, motivation, attitude to life and decision-making. Here we consider the idea of a career based on high school graduates' responses within the research.

\section{Discussion}

The driving force of labor activity is determined by material and spiritual needs. Biological and social inheritance along with the biography is the subjective factor in achieving career goals. Typically, biological and social heredity together with biography can be referred to the subjective factors forming abilities, skills, perceptions, attitudes, values, and so on. In the context of achieving career goals school, where a person spends 11 years, has undoubted influence on the formation of the whole spectrum of these qualities in childhood and adolescence.-

1300 the graduate schools of the city of Krasnoyarsk were interviewed in the study. 1272

(c) Siberian Federal University. All rights reserved

* Corresponding author E-mail address: nla@ippd.ru 
questionnaires were verified on the basis of which the percentage was then analyzed.

Redlining to the perception about a career and so the factors reasoned attitude become primary intent the research.

Just answering questions about career 977 people represent $71.7 \%$ of all the respondents, the distribution of responses is presented in Fig. 1.

The project research team tried to reveal how the factor of schoolinfluences Krasnoyarsk schools graduates' life, labor and educational trajectories, as well as satisfaction with professional activities, family life, social status and life in general. This article continues a series of publications devoted to the study of the influence of education in educational, employment and life trajectories of graduates of educational institutions. [3]

Thecategoricalapparatusandmethodological approach of the present study was formed based on domestic publications [2], including Krasnoyarsk, as well as foreign researchers.

As part of the research objectives through expert survey we identified schools - participants in the study: two - with the concept and program of education, two - the averages, and two - in stagnation areas. It was found that the factor of the school as a whole does not affect the life trajectories, understood as series of events for graduates of different schools, more significant differences are observed in satisfaction, motivation, and the respondents' assessments on all the issues analyzed.

Graduates of secondary schools have various traditional view of "career" as the promotion of human performance or administrative ladder, accompanied with growing wealth, responsibility and the additional work-load. Despite of the similarity in the graduates' responses, significant differences were demonstrated by those who graduated from the conceptual school (Fig. 2): for their career - this is primarily the responsibility, welfare and freedom of action rather than career development. It is possible that their perception of "career" is understood as a synonym of «career development» and reveals this concept through the other. For them internal sensations and ideas are more valuable than the external confirmation in the form of career advancement.

We found a discrepancy in the perception of career between men and women. Men perceive career as a path to prosperity and women - as a promotion.

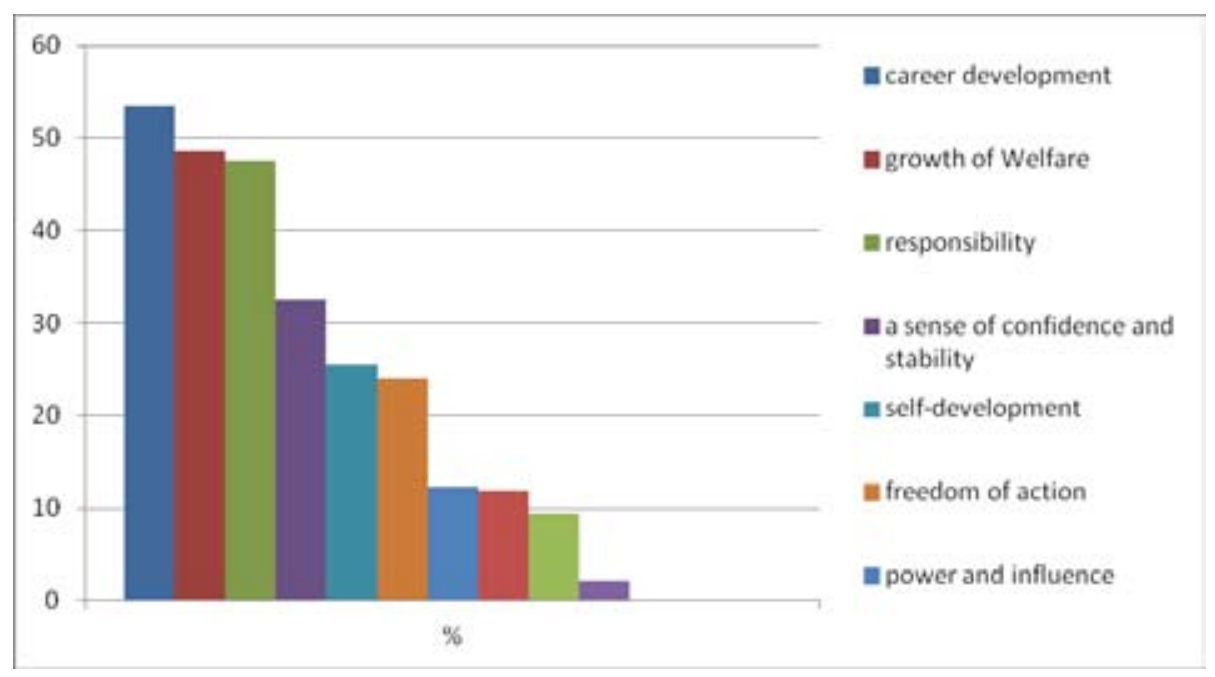

Fig. 1. Distribution of answers to the question "Which of the following corresponds to the concept of "career "? 


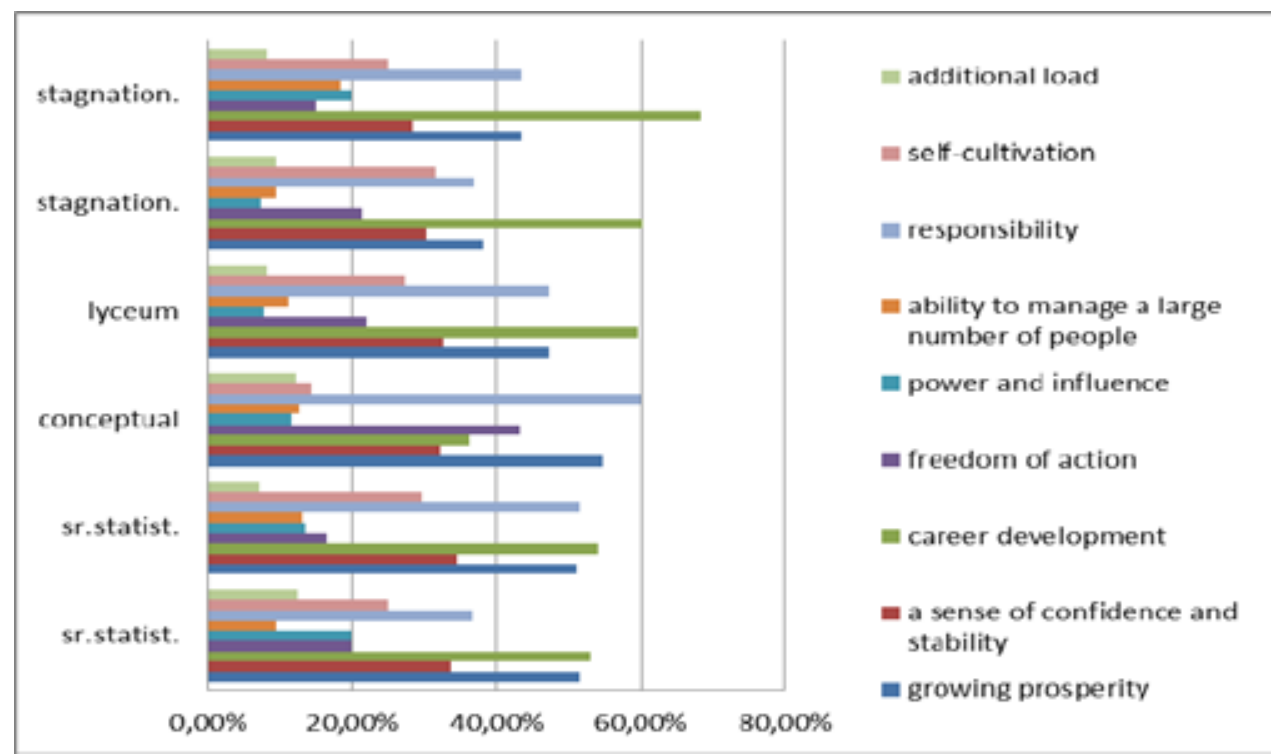

Fig. 2. Notions of "career" of the graduates of different schools

In the following age groups the career concepts are identical: "37 year and over" and "under 25 years"; "30 -36 -year-old" and "25 -29 -year-old".

Most respondents ( $72.3 \%$ ) believe that effort to move along the career ladder is necessary but only two-thirds actually perform. Almost half of those who see no need in career growth in fact make real efforts to advance in their career. The smallest link between the vision of need to apply efforts to gain career success and real acting is observed in the behavior of respondents who graduated from the so-called stagnation schools.

Male, in comparison with female, tend more both to make effort to succeed in career and realize the need. Within the younger generation more of its representatives will endeavor to succeed in career and see the need.

As the main career characteristics the respondents mentioned the criteria used for mention the criteria used for the category occupied in professional activities (social career), satisfaction with the position, career goals and means of achieving them. This might be explained by the fact that within the survey it was difficult to determine the career types that are selected and followed by respondents for professional activities (intra-or inter-organizational, specialized or not, etc.).

Category and type of economic activity of the respondent were determined based on responses to the question "Where and whom for do you work now? (Specify the organization and the position you occupy.) "Most responses are engaged in economic activities, education, public administration; these activities involve the production and provision of services and are based on the specialists work. The actual distribution of respondents by category is shown in Fig. 3 .

The data presented is consistent with the modern economic boundary edge structure and distribution of jobs. Also it was found that the age of the respondents influences, which confirms the thesis about changing social dynamic model of the younger generations: higher education can immediately help to obtain a higher social and professional status in the organizational hierarchy. In this regard, significant differences between 


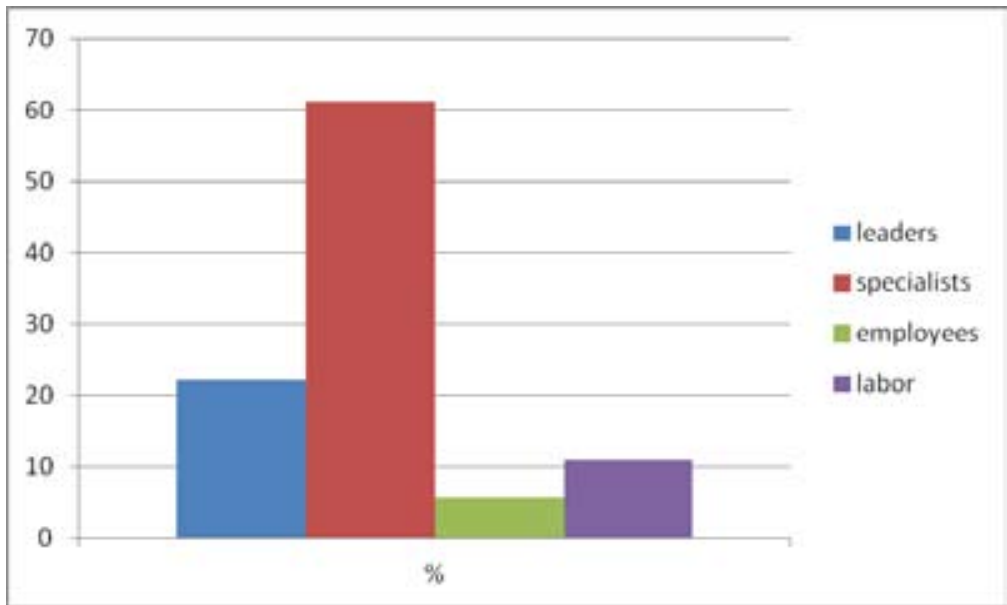

Fig. 3. Distribution of respondents by category

high school graduates were not revealed. Here, we found no significant differences except for a higher entrepreneurship activity by graduated from the stagnation school.

Motivated attitude to the service and being interested in promotion in careers are essential subjective factors that give real benefits in moving up the career ladder. Significant subjective factors are motivation for professional advancement and career interest. These factors give the result in moving up the career ladder. We assumed that the achievements of better results in career are related to ideas about the concept of career.

The data show that such categories of employees as managers, professionals and workers rather choose Non-career goal - family happiness, congenial employment, health and physical perfection. Career goals more important for employees are the following: material wellbeing, autonomy, independence and respect from others.

The greatest number of respondents noted hard work, diligence and education as a means to achieve goals. The greatest differences of opinion on this issue are observed among employees: they evaluate several factors higher than other categories of workers. Such factors include favorable family environment, chance, life circumstances, work place and advantageous marriage. However, employees evaluated below such factors as the training and support for parents.

All respondents indicated that the most frequent reasons for choosing the university were the first high-quality training in the chosen specialty, the prestige of the institution and interesting specialty. The answer is "the possibility of a professional career" is the fourthfifth place as a reason for the choice of university for managers, employees and workers, and the eighth place for professionals. While choosing a university employees to be did not imagine their future career in comparison with specialists and workers.

Thus, we can conclude that the respondents have not yet done social career, guided by practical and short-term results at the time of selecting the first high school. Category of workers focused on employment opportunities immediately after graduation. Employees are guided by the opportunities gained from the training in high school, such as scholarships, trips, internships, exchange programs, and so on. 
In general all the respondents have prioritized equally decent wages and career opportunities in choosing a job. Getting a decent salary is worth slightly more than with the ability to make a career. Despite the fact that employees appreciate more career goals as what they want to achieve in life, they are in employment, they estimate this factor lower.

\section{Conclusion}

This article was focused on the school graduates' ideas about the career. This investigation was limited by the specificity of the sample. We cannot unambiguously identify the types of careers that graduates have chosen and pursued in their professional activity. However as the results of this research, it can be argued that the graduates of conceptual schools have specific ideas about the career. Responsibility, welfare and freedom of action not a formal career development - characterize career for them. This fact allows us to formulate a new hypothesis that the graduates of conceptual school value inner feelings higher than external confirmation in the form of career advancement. In the total sample, graduates of others schools have the traditional notion of "career". The respondents largely celebrate promotion on a service or administrative ladder. Growing prosperity, responsibility for the work done and the additional burden is regarded by them as a consequence of career development. Opportunity to get a decent salary and the opportunity to make a career have equal importance for the respondents when choosing a job. Career goals have a higher rating in the category of employees. In their opinion, it is what is necessary to achieve in life; however, they estimate this factor as very insignificant in employment.

The results indicate the need for further research that will focus on identifying the obvious signs of the school influence in the trajectory of graduates.

\section{References}

1. Grigorieva E.G., Novopashina L.A. (2014) Career in Life Trajectories of High School Graduates. Theory and Practice of Social Development, 6, 68-72. available at: http://www.teoriapractica.ru/rus/files/arhiv_zhurnala/2014/6/

2. Novopashina L.A., Yustus T.I., Grigorieva E.G. and other (2013) Characteristics of Responsibility as a Factor in School Graduates Biography. Pedagogy development: initiative, independence, responsibility: Proceedings of the 19th scientific-practical. conf. Krasnoyarsk, 47-57.

3. Novopashina L.A., Yustus T.I. and Grigorieva E. G. (2012) Factors in the Biography School Graduates. Proceedings SWorld. Proceedings of the international scientific-practical conference "Scientific research and its practical application. Current status and the development of '2012", 3 (17), 25-38. 


\section{Следы школы}

\section{в представлениях выпускников о карьере}

\section{Л.А. Новопашина, Е.Г. Григорьева}

Сибирский федеральный университет Россия, 660041, Красноярск, пр. Свободный, 79

Статья является продолжением авторских публикаций по результатам проведенного в 2011 г. исследования «Следы особенностей образовательной программы и школьв в биографиях выпускников». Выявление факторов, влияющих на представления о карьере на жизненном пути, представляет собой определенные сложности. Результаты анализа данных факторов позволяют объяснить различия в восприятии карьерной мотивации выпускниками разных икол.

Ключевые слова: карьера, отношение к карьере, жизненный путь, образовательная система.

Научная спещиальность: 19.00.00 - психологические науки. 